\title{
IMPLEMENTASI KEBIJAKAN PENANGANAN DAN PENGENDALIAN CORONA VIRUS DISEASE-2019 PADA SEKTOR PARIWISATA DI KOTA TOMOHON
}

\section{THE IMPLEMENTATION OF POLICIES FOR HANDLING AND CONTROLLING COVID-19 VIRUS ON THE TOURISM SECTOR IN TOMOHON CITY}

\author{
$\underline{\text { Steven Rudy Tampah }}^{(1)}$, Maria Heni Pratiknjo ${ }^{(2)}$, Very Yohanis Londa ${ }^{(2)}$ \\ 1) Peneliti dan Pemilik Usaha Independen \\ 2) Staf Pengajar dan Peneliti pada Program Studi Pengelolaan Sumberdaya Pembangunan Pascasarajana, Universitas \\ Sam Ratulangi, Manado \\ *Penulis untuk korespondensi: tampahsevenrudy@gmail.com
}

\author{
Naskah diterima melalui e-mail jurnal ilmiah agrisosioekonomi@unsrat.ac.id : Jumat, 15 Januari 2021 \\ Disetujui diterbitkan \\ : Jumat, 22 Januari 2021
}

\begin{abstract}
The purpose of this study was to analize the implementation of policies for handling and controlling covid-19 on the tourism sector in Tomohon City. The method used in this research is descriptive method using a qualitative approach. The research was conducted in Tomohon City using empirical data obtained through observations and interviews. The results showed that the implementation of policies for handling and controlling covid-19 on the tourism sector was carried out based on standards and policy targets through programs, namely physical distancing and work form home and the Tomohon City government program through the announcement of the mayor of Tomohon and Tomohon Mayor Regulation Number 28 of 2020 which is implemented based on the principles of implementing policies for handling and controlling covid-19 on the tourism sector in Tomohon City. In implementing this policy, communication factors between policy implementers, resources, disposition and bureaucratic structures are very influential in implementation. However, in implementing the policy, there are several weaknesses of these factors, namely the lack of communication between institutions, especially in the tourism sector, for example from the tourism office to the Indonesian Tourism Guides Association in Tomohon City, budget constraints, and lack of human resources as executors either as professionals or as professionals, tourism observers, especially on the tourism sector in the city of Tomohon.
\end{abstract}

Keywords : policy, implementation, Covid-19, tourism

\begin{abstract}
ABSTRAK
Tujuan penelitian ini untuk menganalisis implementasi kebijakan penanganan dan pengendalian covid-19 pada sektor pariwisata di Kota Tomohon. Metode yang digunakan dalam penelitian ini adalah metode deskriptif kualitatif. Penelitian dilaksanakan di Kota Tomohon dengan menggunakan data empiris yang diperoleh melalui pengamatan dan wawancara mandalam. Hasil penelitian menunjukkan bahwa implementasi kebijakan penanganan dan pengendalian covid-19 pada sektor pariwisata dilaksanakan berdasarkan standar dan sasaran kebijakan melalui program-program yaitu physical distancing (jaga jarak) dan work from home (bekerja dari rumah) dan program pemerintah Kota Tomohon melalui maklumat Walikota Tomohon dan Peraturan Walikota (Perwako) Tomohon Nomor 28 Tahun 2020 yang dilaksanakan berdasarkan prinsip-prinsip implementasi kebijakan penanganan dan pengendalian covid-19 pada sektor pariwisata di Kota Tomohon. Dalam implementasi kebijakan ini, faktor komunikasi antar pelaksana kebijakan, sumberdaya, disposisi dan struktur birokrasi sangat berpengaruh dalam pelaksanaan. Namun dalam pengimplementasian kebijakan terdapat beberapa kelemahan dari faktor-faktor tersebut yaitu: kepatutan pengelola dan pengunjung wisata dalam menjalankan pedoman yang ditentukan, keterbatasan anggaran, serta kurangnya sumberdaya manusia sebagai pelaksana baik sebagai tenaga professional ataupun para pemerhati pariwisata khususnya di sektor pariwisata di Kota Tomohon.
\end{abstract}

Kata Kunci : implementasi, kebijakan, Covid-19, pariwisata

Agrisosioekonomi : Jurnal Transdisiplin Pertanian (Budidaya Tanaman, Perkebunan, Kehutanan, Peternakan, Perikanan Ekonomi dan Teknologi Pangan serta Teknologi Pertanian). 


\section{PENDAHULUAN}

\section{Latar Belakang}

Implementasi merupakan tahapan dalam proses pelaksanaan kebijakan publik dimana dilaksanakan setelah perumusan kebijakan yang bertujuan jelas. Implementasi merupakan rangkaian aktivitas dalam menjalankan kebijakan di masyarakat yang bertujuan agar kebijakan yang dibuat dapat memberikan hasil sesuai dengan yang diharapkan yang mencakup dipersiapkannya peraturan - peraturan sebagai peraturan lanjutan sebagai interpretasi kebijakan yang telah dibuat.

Dalam mencapai tujuan implementasi kebijakan, proses penyebaran informasi harus dapat dijalankan dengan baik. Hal tersebut ditujukan kepada kelompok sasaran atau target ataupun individu agar memperoleh informasi serta munculnya kesadaran, menerima serta dapat mempengaruhi perilaku sasaran dan mampu memanfaatkan informasi yang diberikan. Proses tersebut tentunya harus memperoleh respon dari individu atau kelompok, dalam hal ini masyarakat terhadap otoritas pemerintah sebagai pembuat kebijakan yang harus dipatuhi dan dijalankan sesuai dengan undang - undang yang telah dibuat oleh pemerintah sebagai pihak yang berwenang. Individu atau kelompok tentunya harus menerima dan menjalankan kebijakan yang dibuat serta meyakini dibuat secara sah meskipun pada awal kebijakan disampaikan dapat menuai kontroversi yang seiring waktu berjalan dianggap sebagai sesuatu yang wajar.

Salah satu kebijakan yang dikeluarkan oleh pemerintah adalah tentang Pembatasan Sosial Berskala Besar (PSBB) sebagai bentuk percepatan penanganan Corona Virus Disease2019 (Covid-19). Kebijakan tersebut bertujuan untuk melindungai warga dari risiko penularan. Kebijakan tersebut tertuang dalam Peraturan Pemerintah Nomor 21 tahun 2020 tentang Pembatasan Sosial Berskala Besar dalam rangka Percepatan Penanganan Corona Virus Disease2019 (Covid-19) ditetapkan pada 31 Maret 2020. Pemerintah Daerah (Pemda) dapat melakukan Pembatasan Sosial Berskala Besar (PSBB) untuk satu provinsi atau kabupaten/kota tertentu. PSBB dilakukan dengan pengusulan oleh gubernur/ bupati/ walikota kepada pemerintah pusat dalam hal ini oleh Menteri Kesehatan. Dengan adanya pembatasan aktivitas masyarakat, secara otomatis berpengaruh terhadap sektor - sektor yang mempengaruhi pertumbuhan ekonomi. Salah satu sektor yang mempengaruhi pertumbuhan ekonomi adalah sektor pariwisata.

Pariwisata menjadi salah satu industri yang memiliki hubungan atau keterkaitan dengan sektor lain yang sangat kuat. Hal tersebut didukung oleh interaksi dengan wisatawan, pebisnis serta pemerintah, lokasi wisata serta daerah tujuan wisata. Pariwisata menjadi suatu usaha yang kompleks dengan banyaknya aktivitas yang berhubungan dengan penyelenggaraan pariwisata yang terdiri dari perhotelan, kerajinan tangan/cendera mata, travel, dan bebagai jenis usaha lainnya yang berkaitan dengan pariwisata.

Pada pertengahan bulan Maret Tahun 2020, khususnya pada sektor pariwisata, dilakukan penutupan tempat - tempat wisata, termasuk semua yang berkaitan dengan aktivitas pariwisata sebagai salah satu solusi pemerintah dalam menangani permasalahan yang dilanda bahkan oleh seluruh negara - negara dunia yakni pandemi corona virus disease 2019 (Covid-19) oleh pemerintah dikeluarkan kebijakan pembatasan sosial berskala besar atau PSBB yang tentunya berdampak pada sektor pariwisata.

Meluasnya penyebaran covid-19 berdampak pada sektor pariwisata tanpa terkecuali di Kota Tomohon, Provinsi Sulawesi Utara yang memiliki potensi pariwisata yang terkenal akan keindahan yang menjadi pemantik kunjungan wisatawan baik domestik (wisdom) maupun mancanegara (wisman). Potensi pariwisata mulai dari destinasi wisata hingga potensi usaha pariwisata dijadikan tujuan berlibur. Destinasi wisata Kota Tomohon berjumlah 84 destinasi wisata. Beberapa diantaranya seperti Danau Linow hingga pesona alam Gunung Lokon dan Gunung Mahawu, dua gunung berapi aktif yang berdekatan.

Kota Tomohon setiap tahunnya menyelenggarakan pekan internasional yang bertajuk "Tomohon International Flower Festival" atau TIFF yang mendulang jumlah kunjungan wisatawan. Pada Tahun 2020, agenda tahunan pelaksanaan TIFF pun, tidak dapat dilaksanakan dikarenakan pandemi covid-19. Selain itu, Kota Tomohon merupakan salah satu daerah yang berada di Provinsi Sulawesi Utara yang akan mengadakan pemilihan kepala daerah namun terancam ditunda dikarenakan selalu menjadi langganan zona merah penyebaran covid-19 berdasarkan hasil pembobotan skoring dari tim gugus pusat. 
Pemerintah Kota Tomohon, mengambil tindakan tegas dengan menutup sementara tempat wisata sebagai bentuk upaya menjalankan anjuran penerapan WFH atau kerja dari rumah dan physical distancing (jaga jarak fisik) sebagai upaya pencegahan meluasnya covid-19 dengan tujuan agar setiap masyarakat memahami upaya yang dilakukan pemerintah sehingga bisa menahan diri di rumah apabila tidak ada keperluan mendesak (https://sindomanado.com /2020/03/24/ tempatwisata-dan-hiburan-malam-di-kota-tomohonditutup/).

Melalui maklumat Walikota Tomohon, pemerintah Kota Tomohon mengeluarkan peraturan (maklumat) tentang penegasan pelaksanaan himbauan pemerintah dalam penanganan penyebaran covid-19 melalu surat nomor 67/WKT/IV-2020 yang terdiri dari sembilan himbauan. Pada tanggal 1 September 2020, pemerintah Kota Tomohon mengeluarkan Peraturan Walikota (Perwakot) No. 28 sebagai bentuk kelanjutan penerapan penanganan dan pengendalian covid-19 dari maklumat Walikota Tomohon. Pada peraturan tersebut, khusus sektor pariwisata di tekankan pada pasal 3, 4, 5, 7, 8 \& pasal 10. Dalam pelaksanaan peraturan walikota, dilaksanakan oleh para SKPD yang yang terkait, dan untuk sektor pariwisata sendiri penerapan dilaksanakan di sektor - sektor pariwisata yang dijalankan oleh implementor - implementor yang telah ditentukan. Implementor pelaksanaan perwakot di sektor pariwisata terdiri dari, petugas dari dinas pariwisata, TNI, Polri, Polisi Pamong Praja (Pol-PP), BPBD, dinas kesehatan serta oleh organisasi - organisasi yang bergerak dibidang sektor pariwisata diantaranya Himpunan Pramuwisata Indonesia Kota Tomohon.

Dalam pelaksanaan penerapan perwakot tersebut, para implementor memberikan informasi baik kepada masyarakat secara keseluruhan sebagai pelaku wisata serta kepada pengelola tempat - tempat wisata secara intens namun pada kenyataannya masih banyak terlihat pengunjung yang tidak menerapkan himbauan yang disampaikan pemerintah melalui pengelola wisata. Jumlah implementor yang terdiri dari beberapa instansi pemerintah dan swasta, seharusnya perwakot berjalan sesuai dengan yang diharapkan. Masalah yang terlihat dilapangan, pada pelaksanaan banyak masyarakat yang terkena sanksi pada saat dilakukan operasi yustisi yang dilaksanakan oleh TNI, Polri, Pol-PP. Kehadiran petugas - petugas dalam menjalankan tugas sebagai implementor kebijakan dari Perwakot No. 28 tentunya sebagai penerapan untuk memastikan bahwa kebijakan tersebut dijalankan terutama oleh pelaku dan pengelola wisata. Hal tersebut dapat dilihat dari pembagian tugas masing - masing sebagai bentuk koordinasi antar satu dengan yang lainnya. Secara keseluruhan implementor sudah menjalankan tugas sesuai dengan yang diamanatkan, tetapi pelanggaran kebijakan banyak terjadi, salah satunya Tomohon tetap berada pada zona merah covid-19.

Menilik dari kebijakan penanganan dan pengendalian covid-19 yang dilakukan oleh pemerintah pusat Republik Indonesia khususnya di bidang pariwisata, menjadi acuan bagi pemerintah daerah, tanpa terkecuali Pemerintah Kota Tomohon, oleh sebab itu penulis merasa tertarik untuk melakukan penelitian dengan judul "Implementasi Kebijakan Penanganan dan Pengendalian Corona Virus Disease - 2019 Pada Sektor Pariwisata Di Kota Tomohon".

\section{Implementasi Kebijakan Publik}

Implementasi merupakan tindakantindakan yang dilakukan baik oleh individuindividu/pejabat-pejabat atau kelompokkelompok pemerintahan atau swasta yang diarahkan pada tercapainya tujuan-tujuan yang telah digariskan dalam keputusan kebijakan. Menurut Widodo (2011), implementasi merupakan suatu proses yang melibatkan sejumlah sumber yang termasuk manusia, dana, dan kemampuan organisasional yang dilakukan oleh pemerintah maupun swasta (individu atau kelompok). Proses tersebut dilakukan untuk mencapai tujuan yang telah ditetapkan sebelumnya oleh pembuat kebijakan.

Dalam melaksanakan implementasi suatu kebijakan tidak serta merta akan berjalan sesuai yang direncanakan. Keberhasilan suatu kebijakan dipengaruhi oleh banyak faktor. Faktor - faktor yang mempengaruhi implementasi kebijakan publik bertujuan untuk penyederhanaan pemahaman, oleh sebab itu dibutuhkan model implementasi kebijakan. Salah satu penerapan kebijakan yang dilaksanakan berada pada sektor pariwisata. 


\section{Konsep Pariwisata}

Pariwisata adalah perjalanan dari satu tempat ketempat lain bersifat sementara, dilakukan perorangan atau kelompok, sebagai usaha mencari keseimbangan atau keserasian dan kebahagiaan dengan lingkungan dalam dimensi sosial budaya, alam, dan ilmu (Ardika, 2007).

Salah satu permasalahan yang dapat mempengaruhi pariwisata yaitu virus. Diantaranya Corona Virus Disease 2019 atau dikenal covid-19. Virus corona (CoV) adalah keluarga besar virus yang yang dapat menginfeksi burung dan mamalia, termasuk manusia. Menurut World Health Organization (WHO) virus ini menyebabkan penyakit mulai dari flu ringan hingga infeksi pernapasan yang lebih parah seperti MERS-CoV dan SARS$\mathrm{CoV}$. Virus corona yang pertama kali muncul dan menyebar ke manusia berasal dari Kota Wuhan, China pada akhir Desember 2019. Setelah ditelusuri, ternyata beberapa orang yang terinfeksi memiliki riwayat yang sama, yaitu mengunjungi pasar basah makanan laut dan hewan lokal di Wuhan.

\section{Rumusan Masalah}

Uraian latar belakang masalah yang telah dikemukakan, ditarik rumusan masalah dalam penelitian ini yaitu, bagaimana Implementasi Kebijakan Penanganan dan Pengendalian Corona Virus Disease - 2019 Pada Sektor Pariwisata di Kota Tomohon?

\section{Tujuan Penelitian}

Berdasarkan latar belakang masalah dan rumusan masalah yang telah dikemukakan, maka penelitian ini bertujuan untuk menganalisa implementasi kebijakan penanganan dan pengendalian Corona Virus Disease - 2019 pada sektor pariwisata di Kota Tomohon.

\section{Manfaat Penelitian}

Secara akademis, penelitian ini diharapkan dapat menambah khasanah ilmu pengetahuan, terutama dalam bidang manajemen sumber daya khususnya. Penelitian ini diharapkan memberi manfaat melalui analisis yang dipaparkan pada pihak - pihak yang bergelut dalam pengambilan kebijakan dan juga kepada masyarakat sebagai subyek pelaksanaan kebijakan. Kebijakan menjadi suatu panduan untuk memecahkan permasalahan yang dihadapi yang dilaksanakan sesuai dengan tahapan tahapan kebijakan. Melalui kajian ini juga, diharapkan, masyarakat, pemerintah sebagai pembuat kebijakan memiliki referensi bacaan dan diskusi yang menambah wawasan tentang kebijakan percepatan penanganan dan pengendalian covid-19 pada khususnya dan kebijakan percepatan penanganan pada bencana non alam secara umum.

\section{METODE PENELITIAN}

\section{Waktu dan Lokasi Penelitian}

Waktu yang digunakan peneliti untuk penelitian ini dilaksanakan dalam kurun waktu kurang lebih 3 (tiga) bulan, yang dimulai dari proses penyusunan proposal, proses pembimbingan dan penyajian dalam bentuk tesis. Penelitian ini dilaksanakan di Kota Tomohon, Provinsi Sulawesi Utara.

\section{Metode Pengumpulan Data}

Penelitian ini menggunakan teknik pengumpulan data meliputi observasi, wawancara dan dokumentasi. Teknik analisa data dalam penelitian ini terdari tahap reduksi data, display data dan kesimpulan atau verifikasi menurut Miles dan Huberman (1992), yaitu: Reduksi data, penyajian data, penarikan kesimpulan/ verifikasi.

\section{Fokus Penelitian}

Fokus penelitian ini adalah keberhasilan implementasi kebijakan penanganan dan pengendalian corona virus disease - 2019 pada sektor pariwisata di Kota Tomohon yang akan diamati didasarkan pada model George Edward III dalam Subarsono, 2011) yang terdiri dari :

1.Komunikasi, tindakan sosialisasi, implementasi kebijakan yang mengatur aktivitas masyarakat dan pengelola wisata, pedoman penanganan dan pengendalian covid-19 pada sektor pariwisata di Kota Tomohon.

2. Sumberdaya, manusia sebagai implementor kebijakan dan anggaran/ sumber dana serta fasilitas - fasilitas yang menunjang pelaksanaan kebijakan penanganan dan pengendalian covid-19 pada sektor pariwisata di Kota Tomohon. 
3. Disposisi, sikap pelaku kebijakan-kebijakan sebagai pelaksana dalam menjalankan kebijakan penanganan dan pengendalian covid-19 pada sektor pariwisata di Kota Tomohon.

4. Struktur Birokrasi, SOP pelaksana kebijakan penanganan dan pengendalian covid-19 pada sektor pariwisata di Kota Tomohon.

\section{Sumber Data Penelitian}

Sumber data dalam penelitian ini adalah data primer dan data sekunder. Data primer adalah data yang diperoleh langsung dari informan. Informan dalam penelitian ini yaitu informan yang memahami informasi tentang objek penelitian menggunakan teknik purposive sampling. Peneliti menentukan informan penelitian dalam penelitian ini berjumlah 15 orang, terdiri dari:

1. BPBD Kota Tomohon (1 orang)

2. Dinas Pariwisata Kota Tomohon (2 Orang)

3. Camat di Kota Tomohon (1 orang)

4. Pengelola Obyek Wisata di Kota Tomohon (4 orang)

5. TNI (1 orang)

6. Polri (1 orang)

7. Tokoh Masyarakat (5 orang)

\section{Metode Analisis Data}

Penelitian menggunakan metode deskriptif kualitatif yang bertujuan untuk memberikan gambaran suatu fenomena atau kenyataan sosial secara jelas yang sesuai dengan permasalahan yang diteliti yaitu implementasi kebijakan penanganan dan pengendalian covid-19 di Kota Tomohon. Penelitian ini menggunakan model penelitian kualitatif. Penelitian kualitatif bertujuan memperoleh gambaran seutuhnya mengenai suatu hal menurut pandangan manusia yang diteliti. Penelitian kualitatif berhubungan dengan ide, persepsi, pendapat, atau kepercayaan orang yang diteliti; kesemuanya tidak dapat diukur dengan angka (Basuki, 2006).

\section{PEMBAHASAN}

Pemerintah Kota Tomohon, mengeluarkan peraturan baik untuk individu (perorangan) maupun pelaku usaha melalui Peraturan Walikota (Perwako) Tomohon Nomor 28 Tahun 2020 yang tertanggal 1 September 2020, tentang penerapan disiplin dan penegakan hukum protokol kesehatan sebagai upaya pengendalian covid-19.
Dalam menjalankan penanganan dan pengendalian covid-19 tentunya dapat berjalan sesuai dengan yang diharapkan. Implementasi kebijakan tidak dapat dijalankan apabila tujuantujuan dan sasaran diidentifikasi berdasarkan keputusan kebijakan yang dibuat. Implimentasi merupakan proses yang dilakukan oleh beberapa faktor yang bertujuan untuk memperoleh hasil sesuai dengan tujuan dan sasaran dari kebijakan yang dibuat.

Hasil wawancara yang dilakukan peneliti di Dinas Pariwisata pada tanggal 10 Oktober 2020 dengan Sekretaris Dinas Pariwisata, menyampaikan bahwa :

"Tujuan kebijakan penanganan dan pengendalian covid-19 khususnya di sektor pariwisata Kota Tomohon dibuat untuk melindungi masyarakat secara keseluruhan serta pengelola dan pelaku usaha agar dapat meminimalisir kejadian covid-19 terutama tidak muncul cluster baru dari obyek wisata".

Sedangkan Sasaran kebijakan penanganan dan pengendalian covid-19 menurut Kepala Pelaksana BPBD Kota Tomohon yang diwawancara pada tanggal 19 Oktober 2020, yaitu :

"Masyarakat secara umum termasuk pelaksana perintah serta pembuat kebijakan itu sendiri. Untuk di tempattempat obyek wisata, termasuk restoran, hotel dan lain - lain, kebijakan tersebut dibuat untuk melindungi pengunjung dan pengelola itu sendiri. Oleh sebab itu pemerintah bersama dinas - dinas terkait sering melakukan operasi yustisi untuk melakukan pengawasan".

Hal tersebut di dukung oleh hasil wawancara yang dilakukan oleh peneliti kepada TNI, Polri dan Sat Pol PP sebagai pimpinan operasi Yustisi Perwako No. 28 Tahun 2020 Kota Tomohon yang dilakukan pada saat operasi yustisi berlangsung yang mengatakan, bahwa : "Operasi yustisi yang dilakukan ini, bukan hanya dilakukan di jalan raya seperti pada saat ini, tetapi kami sebagai tim, baik dari teman - teman TNI, Polri, SatPol PP serta instansi lainnya, kami juga melakukan operasi yustisi di tempat - tempat wisata. Operasi ini sudah dilakukan semenjak bulan April sampai sekarang dan akan terus dilaksanakan sambil menunggu informasi (arahan) selanjutnya. Intinya semua yang dilakukan pemerintah, untuk mengingatkan kepada masyarakat, terlebih pada saat melakukan perjalanan kemana, termasuk ke tempat-tempat wisata, baik diperjalanan maupun sudah dilokasi wisata, tetap melaksanakan protokol sesuai peraturan yang dibuat". 
Menurut hasil wawancara serta pengamatan yang dilakukan peneliti secara langsung, upaya penanganan dan pengendalian covid-19 dapat dikatakan bahwa pemerintah Kota Tomohon melakukan berbagai upaya untuk menangani penyebaran covid-19 dengan sasaran kebijakan yang jelas. Perwako 28 tahun 2020 mengatur sejumlah hal termasuk kewajiban hingga sanksi bagi masyarakat yang melanggar Perwako.

Pendekatan yang digunakan dalam menganalisis implementasi kebijakan penanganan dan pengendalian covid-19 pada sektor pariwisata di Kota Tomohon yaitu teori yang disampaikan oleh George C. Edwards. Menurut Edwards III, terdapat empat faktor yang mempengaruhi kebijakan publik, dimana faktor-faktor tersebut terdiri dari komunikasi, sumber daya, disposisi dan struktur birokrasi. Pengaruh keempat faktor adalah sebagai berikut:

a) Komunikasi

Komunikasi internal yang dimaksud dalam penelitian ini yaitu komunikasi yang terjadi antar pejabat yang berwenang yang melibatkan, TNI, Polri, dinas pariwisata, dinas kesehatan, BPBD, camat, pengelola obyek wisata, restoran, penginapan, tokoh masyarakat serta unsur lainnya seperti yang tercantum dalam peraturan walikota no. 28 tahun 2020 pasal 10 ayat (3).

Hasil wawancara dengan Kepala Seksi Pelayanan Umum di Kecamatan Tomohon Selatan (perwakilan camat) pada 20 Oktober 2020, menyampaikan bahwa :

"Penanganan virus korona (covid-19) sesuai dengan arahan yang berasal dari Pemerintah Kota Tomohon. Arahan tersebut diterima langsung oleh seluruh camat serta pimpinan forum komunikasi pimpinan yang berada di masing masing kecamatan di Kota Tomohon termasuk para lurah. Selanjutnya informasi tersebut disampaikan kepada masyarakat melalui kepala jaga serta perangkat - perangkat yang ada. Informasi tersebut juga disampaikan kepada pengelola obyek wisata yang berada di Kota Tomohon, untuk Kecamatan Tomohon Selatan sendiri, obyek wisata yang paling dikenal yaiu obyek wisata Danau Linouw. Pemerintah kecamatan, bersama dengan kepolisian, TNI, BPBD dan dinas terkait, selalu melakukan operasi yustisi dengan melakukan kunjungan langsung di tempat - tempat wisata".
Sedangkan kejelasan informasi yang disampaikan tersebut, berdasarkan hasil wawancara dengan tokoh masyarakat yang berdampingan dengan lokasi wisata, HM, pada tanggal 21 Oktober 2020 mengatakan bahwa :

"Dari pemerintah Kota Tomohon, mengeluarkan maklumat, dan jujur saya sendiri hanya tahu tentang maklumat saja, baru tahu kalau ada peraturan yang dikeluarkan oleh pemkot Tomohon. Saya tahu, sekarang disaat bapak memberi info kepada saya (Perwako no. 28 tahun 2020). Tapi intinya, saya sendiri mendukung peraturan yang dibuat pemerintah. Pakai masker, jaga jarak, itu yang paling utama".

Hal yang sama disampaikan juga oleh pengelola rumah makan, ibu RT yang diwawancarai pada 22 oktober 2020 yang keseharian berjualan di lokasi wisata, mengatakan bahwa :

"Dengan adanya maklumat yang sudah dipajang hampir dimana-mana, semua info-info tentang pakai masker, cuci tangan dan lain-lain saya dapat dari info di FB, WA dan ada yang saya baca dan dengar melalui televisi. Saya sendiri sebagai penjual makanan, ya.....pendapatan memang berkurang jauh setelah adanya korona ini. Tapi untuk menjaga keselamatan diri sendiri dan keluarga, saya memilih untuk tidak berjualan. Dan tentunya ikuti himbauan dari pemerintah tentang pakai masker, rajin cuci tangan dan terlebih penting diam di rumah. Kadang meskipun ada keperluan mendesak, saya lebih memilih untuk diam dirumah. Terlebih pada waktu itu (kasus covid-19) berada pada tahap yang menakutkan. Banyak kejadian meninggal. Baca melalui FB (facebook), dengar berita di televisi dan ada dari petugas kesehatan puskesmas yang setiap hari menyampaikan informasi melalui pengeras suara dari mobil ambulance puskesmas".

Hasil wawancara pada pengelola obyek wisata (Bukit Doa, Danau Linow dan Taman Bunga Mahoni, Kaisanti), dari keempat pengelola wisata, masing - masing PA, ML, SW dan MK mengatakan bahwa : 
"Dari dinas pariwisata datang berkunjung dan menginfokan tentang peraturan pemerintah. Kami juga sering dipanggil perwakilan - perwakilan pengelola tempat wisata termasuk dari hotel-hotel untuk mengikuti pelatihan tentang protokol covid-19. Intinya sebagai pengelola obyek wisata, kami harus menyediakan tempat cuci tangan termasuk sabun. Kami mengikuti protokol kesehatan yaitu pengunjung harus mencuci tangan, pakai masker dan tentunya membatasi pengunjung agar tidak menciptakan kerumunan. Setiap hari sabtu atau minggu, petugas dari dinas pariwisata dan BPBD selalu data untuk menyemprotkan desinfektan terlebih diruangan sampai ke WC. Kalau hari libur petugas dating dan kalau ada yang tidak mengikuti protokol, tidak pakai masker, maka akan langsung ditegur”.

Berdasarkan hasil wawancara yang dilakukan dapat dikatakan bahwa proses komunikasi yang terjadi sebagai bentuk implementasi kebijakan penanganan dan pengendalian covid-19 di sektor pariwisata di Kota Tomohon berjalan dengan baik. Penyampaian informasi dari implementor dalam memahami informasi yang disampaikan sama dengan apa yang disampaikan pembuat kebijakan yakni pemerintah Kota Tomohon.

b) Sumber Daya

Salah satu faktor yang mempengaruhi implementasi kebijakan yaitu sumber daya dikarenakan proses implementasi kebijakan memerlukan dukungan sumber daya baik dari sumber daya manusia maupun sumberdaya finasial untuk menjalankan implementasi kebijakan yang telah dibuat.

1). Sumberdaya Manusia

Menurut Sekretaris Dinas Pariwisata :

"Kalau dilihat dari jumlah pegawai, memang kami sangat kurang terlebih pada situasi saat ini. Dimana kami harus melakukan pengawasan yang intensi untuk tempat - tempat pariwisata, hotel, restoran yng tentunya tidak akan mencukupi".

Wawancara yang dilakukan pada staf dinas pariwisata, YG, diwawancarai pada 10 Oktober 2020, menjelaskan bahwa :
"Jumlah staf di Dinas Pariwisata Kota Tomohon masih sangat kurang yang menyebabkan seluruh staf memiliki pekerjaan ekstra yang tentunya dituntut untuk menyelesaikan pekerjaan namun tidak selurhnya dapa menyelesaikan pekerjaan yang diberikan karena terkadang berada diluar kemampuan yang menyebabkan dalam melaksanakan kebijakan menjadi tidak efektif. Ada yang harus ke lokasi obyek wisata, untuk melakukan pengawasan, kemudia begitu selesai harus membuat laporan yang terkadang bertabrakan dengan waktu harus melakukan pengawasan di tempat lainnya. Kami agak terbantu, pada saat adanya operasi yustisi, yang dilaksanakan bersama-sama dengan TNI, Poli, SatPol PP. Jadi disaat ada operasi yustisi, kami bisa menyesuaikan staf atau pegawai yang bisa mewakili atau mendampingi pada saat akan melakukan sidak di tempat-tempat wisata".

2) Sumberdaya Finansial/Anggaran

Selain sumberdaya manusia, sumberdaya anggaran/finansial merupakan faktor yang ikut memberikan pengaruh dalam pelaksanaan implementasi kebijakan penanganan dan pengendalian covid-19 pada sektor pariwisata khususnya di Kota Tomohon. Dimana anggaran yang dibutuhkan diambil dari APBD Kota Tomohon, yang pada saat pandemi terjadi, perekonomian dapat dikatakan berjalan di tempat, bahkan tidak berjalan sama sekali.

Menurut Sekretaris Dinas Pariwisata Kota Tomohon pada saat diwawancara mengatakan bahwa :

"Terus terang untuk anggaran dalam pelaksanaan penanganan dan pengendalian covid-19 ini, kami dari Dispar sangat kekurangan dana. Dana yang diperoleh untuk pelaksanaan ini, dimanfaatkan untuk penyediaan masker, tong air, sabun, namun hanya diberikan langsung kepada masyarakat pada saat melaksanakan operasi yustisi maupun pada saat melakukan pengawasan tapi sebatas masker. 
Untuk penyediaan tong air untuk mencuci tangan di obyek - obyek pariwisata, dinas bersama dengan tim dan instansi terkait pada saat melaksanakan pengawasan, menganjurkan di tempat - tempat wisata, hotel, restoran untuk menyediakan tempat cuci tangan dan sabun atau sanitizer. Dengan kata lain, obyek - obyek wisata, restoran, penginapan atau hotel membantu pemerintah secara keseluruhan untuk menyediakan perlengkapan untuk menunjang protokol kesehatan. Kami coba menjelaskan tentang kekurangan anggaran dan mereka memberikan respon yang baik dengan menyediakan apa yang disampaikan dalam hal ini oleh pemerintah. Intinya sebagian fasilitas seperti yang saya sampaikan tadi, memng dibantu oleh pihak pengelola, baik di obyek-obyek wisata, hotel dan rumah makan".

Hasil wawancara dan pengamatan menunjukkan bahwa sumber daya manusia dan sumber daya anggaran pada pelaksanaan implementasi kebijakan penanganan dan pengendalian covid-19 pada sektor pariwisata di Kota Tomohon tidak ter-cover secara penuh. Hal tersebut nampak dari pelaksana atau implementor dari dinas pariwisata sendiri yang memiliki kekurangan staf/pegawai serta anggaran yang dibutuhkan untuk melaksanakan kebijakan sebagai suatu bentuk implementasi kebijakan.

c) Disposisi (Sikap Pelaksana)

Hasil wawancara yang dilakukan bersama Bhabinkamtibmas Polres Tomohon pada saat operasi yustisi, mengatakan bahwa
"Kami selalu mengutamakan kepentingan masyarakat, karena ini salah satu bentuk pelayanan kami kepada masyarakat. Covid-19 ini kan tidak memandang bulu siapa yang akan kena, kami juga petugas yang menjalankan peraturan ini sebagai suatu kebijakan untuk penanganan covid-19 ini, rasa takut terpapar memang ada, makanya kami melengkapi diri, pakai masker,

\begin{abstract}
cuci tangan dan itu juga kami himbau kepada masyarakat. Baik dijalan, tempat - tempat makan, tempat wisata dan kami menjalankannya dengan rasa penuh tanggungjawab. Sama seperti saya sampaikan, kami semua sebagai pelaksana kebijakan yang mengawal peraturan pemerintah ini, menjalankannya dengan sukacita dan tanggung jawab secara penuh".
\end{abstract}

Hal senada disampaikan oleh pengawas protokol covid-19 dari TNI pada saat mengadakan operasi yustisi, menjelaskan bahwa :

"Rasa lelah, rasa capek, rasa takut terpapar memang ada. Tapi tanggung jawab kami melindungi masyarakat. Seperti pada operasi yustisi ini, kami menerapkan peraturan pemerintah ini, dengan menghimbau masyarakat. Apabila ada yang melanggar, kami memberika sanksi dalam hal ini, menyanyikan lagu kebangsaan dan diminta untuk membuat surat pernyataan tntunya dengan cara persuasive serta dengan cara - cara yang bisa sopan, baik dan dapat diterima pelanggar".

d) Struktur Birokrasi

Hasil wawancara yang dilakukan oleh peneliti kepada Sekretaris Dinas Pariwisata Kota Tomohon, dikatakan bahwa:

"Kami belum memiliki SOP untuk pelaksanaan peraturan ini tetapi memiliki alur yang sebelumnya sudah dirapatkan di dinas pariwisata ini. Kami melaporkan langsung, melalui kepala dinas, dan kepalsa dinas yang menyampaikan laporan tersebut kepada pemerintah Kota Tomohon, sebagai pembuat kebijakan. Nanti akan saya berikan alurnya untuk bapak".

Didasarkan pada hasil wawancara tersebut, dinas pariwisata Kota Tomohon dapat dikatakan belum memiliki SOP namun memiliki alur yang telah ditetapkan melalui rapat yang dilaksanakan di dinas pariwisata tentang penanganan dan pengendalian covid19 pada sektor pariwisata di Kota Tomohon. Hambatan yang dihadapi dalam pengimplementasian kebijakan penanganan 
dan pengendalian covid-19 pada sektor pariwisata di Kota Tomohon menurut Sekretaris Dinas Pariwisata Kota Tomohon mengatakan bahwa :

"Penanganan covid-19 khususnya di sektor pariwisata secara keseluruhan berjalan lancar, namun kendala yang dihadapi yaitu anggaran pelaksanaan. Kalau bapak sebagai peneliti mengunjungi tempat - tempat pariwisata atau di penginapan, rumah makan, semua terdapat tong - tong air, sabun cuci tangan ataupun hand sanitizer, semua itu disiapkan oleh pengelola sendiri sebagai himbauan pemerintah. Karena seperti yang saya katakana tadi bahwa anggaran kurang. Semua diambil dari APBD tapi karena adanya krona, perekonomianpun terganggu yang secara otomatt pemasukan ke kas daerah sangat kurang bahkan hamper tidak ada sama sekali”. (Hasil wawancara 10 Oktober 2020).

Selain itu, hambatan implementasi kebijakan terhambat pada kepatuhan dari pengelola obyek wisata, hotel/penginapan dan restoran. Tidak dapat dipungkiri asda beberapa obyek pariwisata yang tidak menjalankan secara keseluruhan tentang protokol kesehatan sebagai pedoman. Hasil wawancara dengan staf Dinas pariwisata bpk YG, mengatakan bahwa :

"Kalau pergi ke tempat - tempat wisata, semua memang ada tong air, tempat cuci tangan, tetapi lain hanya dijadikan sebagai pajangan saja. Kami pernah melakukan sidak di obyek wisata, dan ada obyek wisata yang tidak melaksanakan pedoman. Jadi pengunjung dating, bayar karcis masuk dan dipersilahkan kelokasi tanpa ada pemeriksaan suhu tubuh, tidak mencuci tangan, dan sebagian besar pengunjung tidak menggunakan masker" (Hasil wawancara tanggal 10 Oktober 2020).

Hasil wawancara peneliti dengan beberapa pengelola obyek wisata mengatakan bahwa :

"Kami disini menyediakan tempat cuci tangan, sabun dan petugas di pintu masuk menggunakan masker. Tetapi kalau ada pengunjung kadang masker diturunkan karena berbicara dengan pengunjung terasa sesak nafas karena ditutupi lama. Cuma kalau pengunjung dating, rata - rata bawa kendaraan masing - masing, kami hanya meminta uang karcis masuk, dan memang tidak mengukur suhu, pokoknya selesai bayar karcis pengunjung diijinkan masuk. Setelah didalam pengunjung bebas untuk berfoto dan melakukan kegiatan namun kami mengingatkan untuk mengikuti protokol yang disampaikan tetapi semua kembali kepada pengunjungnya apakah mau pakai masker atau tidak, karena jujur tidak enak kan kalau kami harus tegur langsung" (Hasil wawancara tanggal 18 Oktober 2020).

Berdasarkan hambatan - hambatan yang ada dalam proses pengimplementasian kebijakan penanganan dan pengendalian covid-19 pada sektor pariwisata di Kota Tomohon maka pemerintah Kota Tomohon dalam hal ini dinas pariwisata tetap melakukan sosialisasi baik dengan mengunjungi langsung, melalui media sosial dan berbagai sarana yang dapat menunjang sosialisasi. Pernyataan ini sesuai dengan hasil wawancara dengan Sekretaris Dinas Pariwisata Kota Tomohon yang menyebutkan bahwa :

"Memang dari dinas pariwisata sendiri, kami kekurangan staf untuk mengunjungi langsung ke tempat - tempat wisata. Tapi kalu kami rasa bisa dengan berbagi tugas, kami ada tim yang turun ke lapangan. Namun kami juga berbagi informasi, sosialisasi melalui grup WA, grup FB serta melalui Koran digital pokoknya yang bias membantu kami dalam proses sosialisai, terutama pakai masker, dan cuci tangan”.

Selain sosialisasi melalui menggunakan media, pemerintah melaksanakan operasi yustisi dimana operasi yustisi dilaksanakan oleh seluruh instansi terkait, yakni, Pemkot Tomohon secara keseluruhan, TNI dan Polri. Selanjutnya upaya dari pemerintah Kota Tomohon yaitu dengan membuat peraturan Walikota No. 28 Tahun 2020 menjadi Undang - Undang dan pengamatan peneliti, pemerintah juga hampir di setiap pertigaan, perampatan jalan terdapat baliho baliho yang dipajang tentang himbauan penanganan dan pengendalian covid-19 di Kota Tomohon.

Implementasi kebijakan penanganan dan pengendalian covid-19 pada sektor pariwisata di Kota Tomohon dilakukan berdasarkan standar oprasional prosedur serta pedoman yang telah 
ditentukan oleh pemerintah yaitu pemerintah Kota Tomohon sebagai pembuat kebijakan. Kebijakan yang tertuang dalam Perwako No. 28 tahun 2020 tentang penanganan dan pengendalian covid-19. Petugas sebagai implementor kebijakan, khususnya pada bidang pariwisata yakni, dinas pariwisata Kota Tomohon beserta SKPD yang terkait harus melaksanakan tahapan dan melaksanakan tugas sebagai bentuk tindakan sesuai dengan kewenangan yang ditentukan dan digariskan dalam kebijakan yang telah dibuat sesuai arahan Menteri Dalam Negeri pada surat edaran.

Proses pelaksanaan implementasi kebijakan penanganan dan pengendalian covid19, tidak secara keseluruhan berjalan dengan lancar dimana terdapat kendala-kendala yang menjadi hambatan dalam proses implementasi kebijakan. Hambatan tersebut merupakan suatu kendala yang mendasari hambatan yaitu dari sumberdaya manusia, anggara atau dana yang tersedia serta proses komunikasi oleh implementor dan kepatuhan dari pelaku kebijakan dalam hal ini masyarakat dan pengelola obyek wisata yang terdiri dari restoran/rumah makan, hotel/penginapan, obyek wisata lainnya.

Oleh sebab itu hambatan atau kendala yang ada tersebut di analisis menggunakan teori model implementasi kebijakan menurut George Edwards III dimana model implementasi kebijakan ini dipengaruhi empat variabel, yaitu komunikasi, sumberdaya, disposisi dan struktur birokrasi.

Komunikasi merupakan satu hal penting dalam mengimplementasikan sebuah kebijakan. Hal tersebut dikarenakan kebijakan berjalan secara efektif apabila dalam pelaksanaannya dipahami isi yang menjadi tujuan dan maksud dari kebijakan yang dibuat, sehingga maksud dan tujuan kebijakan dapat terlihat dalam peraturan yang telah dibuat. Kegagalan dalam proses implementasi kebijakan dapat terjadi yang diakibatkan oleh samarnya suatu isi kebijakan serta tujuan kebijakan dan ketidakjelasan sasaran kebijakan.

Hasil penelitian dalam rangka upaya penyelenggaraan penanganan dan pengendalian covid-19 pada sektor pariwisata di Kota Tomohon, dapat dikatakan bahwa sejauh ini Pemerintah Kota Tomohon melalui dinas pariwisata telah berupaya untuk menangani permasalahan covid-19 dengan sasaran serta tujuan yang jelas. Komunikasi antar pembuat kebijakan, pelaksana (implementor) serta sasaran dari kebijakan menjadi suatu tahap awal dalam pengimplementasian kebijakan.

Sumber daya menjadi suatu syarat keberhasilan dalam pengimplementasian kebijakan. Sumberdaya manusia dalam penanganan dan pengendalian covid-19 di dinas pariwisata masih sangat kurang sehingga dinas pariwisata Kota Tomohon melakukan upaya dengan cara mengoptimalkan kinerja para staf agar dapat menyelesaikan pekerjaan yang ada, dimana upaya yang dilakukan ini masih kurang maksimal, dikarenakan selain membebani pekerjaan yang sudah diluar kemampuan, pegawai di dinas pariwisata banyak menjalankan perkerjaan dari rumah dan dapat menyebabkan jalannya kebijakan tidak menjadi efektif.

Sumberdaya anggaran pelaksanaan kebijakan ini mengandalkan dari APBD Kota Tomohon serta dapat dikatakan berasal dari donatur - donatur dalam hal ini pengelola wisata sendiri. Keterbatasan anggaran tersebut menyulitkan implementor dalam melaksanakan tugas dilapangan.

Implementasi kebijakan penanganan dan pengendalian covid-19, kesungguhan serta kemauan implementor dalam menjalankan implementasi kebijakan ini dapat dikatakan sudah baik meskipun dengan berbagai kendala yang muncul salah satunya dari fasilitas, tetapi para implementor tetap berusaha dengan cara mensiasati seperti menggunakan fasilitas pribadi demi lancarnya pelaksanaan kebijakan.

Menurut teori George Edwards III, struktur birokrasi mencakup dimensi penyebaran tanggung jawab dalam suatu kebijakan kepada unsur - unsur yang berbeda beda oleh sebab itu diperlukan koordinasi. Selanjutnya, birokrasi sendiri terdapat SOP yang dapat mempermudah serta menyamakan tindakan dari pra implementor kebijkanan dalam melaksanakan tugas masing - masing.

Hasil pengamatan dan wawancara, struktur birokrasi di dinas pariwisata Kota Tomohon menggambarkan jelas pembagian kegiatan atau tugas antara kelompok yang satu dengan kelompok yang lainnya. Implementasi kebijakan penanganan dan pengendalian covid19 pada sektor pariwisata di Kota Tomohon tidak memiliki SOP tetapi memiliki alur sebagai pedoman atau prosedur dalam pelaksanaan. Hal ini sesuai dengan hasil wawancara peneliti dengan sekretaris dinas pariwisata Kota Tomohon. 


\section{KESIMPULAN DAN SARAN}

\section{Kesimpulan}

Berdasarkan hasil penelitian dan pembahasan yang telah dijelaskan diatas, peneliti menarik kesimpulan bahwa :

1. Implementasi kebijakan penanganan dan pengendalian corona virus disease 2019 pada sektor pariwisata di Kota Tomohon dapat dikatakan berjalan sesuai dengan yang diharapkan meskipun terdapat beberapa hambatan dalam pelaksanaannya. Implementasi kebijakan penanganan dan pengendalian corona virus disease 2019 pada sektor pariwisata di Kota Tomohon dapat dijelaskan dengan rincian sebagai berikut :

a) Komunikasi

Sosialisasi yang dilaksanakan oleh para implementor sudah dijalankan secara maksimal. Hal tersebut dapat dilihat dari kunjungan instansi terkait ke obyek - obyek pariwisata secara intens, kemudian dari petugas puskesmas memberikan informasi melalui kendaraan operasional tentang covid19, serta keterlibatan para pelaku, pengelola obyek wisata yang menyediakan sarana penunjang dalam melaksanakan protokol kesehatan yang diinfokan pemerintah untuk disediakan dan dijalankan. Masyarakat (wisatawan) dan pengelola tetap mematuhi protokol kesehatan yaitu menggunakan masker, mencuci tangan dengan sabun ataupun menggunakan sanitizer dan tetap menjaga jarak.

b) Sumberdaya

Secara umum dalam penanganan dan pengendalian covid-19 pada sektor pariwisata di Kota Tomohon memiliki sumberdaya manusia dan anggaran yang kurang. Berdasarkan kualitas sumberdaya manusia yang dimiliki, jumlah implementor memenuhi syarat namun dari segi kuantitas, implementor memiliki jumlah personil yang kurang, menyebabkan pengawasan tidak dapat dijalankan secara maksimal.

c) Disposisi

Pelaksanaan implementasi kebijakan penanganan dan pengendalian covid-19 pada sektor pariwisata di Kota Tomohon, pelaksana kebijakan sebagai implementor, mampu menunjukkan sikap yang baik yaitu dengan menunjukkan komitmen, kejujuran dan demokratis.

c) Struktur Birokrasi

Secara keseluruhan, Kota Tomohon memiliki struktur birokrasi yang jelas dalam penanganan dan pengendalian covid-19. Untuk Dinas pariwisata Kota Tomohon tidak memiliki standart operational procedure namun memiliki alur dalam mengimplementasikan kebijakan penanganan dan pengendalian covid-19 pada sektor pariwisata di Kota Tomohon sebagai pedoman. Namun wewenang implementor dalam melaksanakan kebijakan penanganan dan pengendalian covid-19 hanya pada apa yang diperintahkan oleh pimpinan dalam hal ini pemerintah Kota Tomohon sebagai pembuat kebijakan yang menyebabkan tidak dapat mengambil keputusan cepat pada situasi - situasi tertentu.

2. Faktor-faktor yang menghambat implementasi kebijakan penanganan dan pengendalian covid-19 pada sektor pariwisata di Kota Tomohon terdiri dari :

a) Jumlah SDM yang terbatas, menyebabkan program pelaksanaan penanganan dan pengendalian covid-19 pada sektor pariwisata di Kota Tomohon masih dapat dikatakan belum optimal.

b. Anggaran yang tersedia tidak dapat memenuhi/mencukupi kebutuhan dalam pelaksanaan kebijakan.

c. Kepatuhan dari pengelola obyek wisata dalam menerapkan protokol kesehatan dalam hal ini pedoman yang telah disosialisasikan oleh pemerintah, dalam hal ini oleh dinas pariwisata Kota Tomohon.

d. Wisatawan/masyarakat yang berkunjung ke obyek - obyek wisata namun tidak memperhatikan himbauan baik secara lisan oleh pengelola obyek wisata (terkesan cuek) maupun himbauanhimbauan dalam bentuk baliho, pamflet yang dipasang di obyek-obyek pariwisata.

Implementasi kebijakan penanganan dan pengendalian covid-19 pada sektor pariwisata di Kota Tomohon telah berjalan dengan baik meskipun terdapat kendala-kendala dalam proses implementasinya. 


\section{Saran}

Hasil pembahasan dan kesimpulan yang telah dijelaskan, maka untuk mengatasi/ memperbaiki kendala-kendala yang ditemukan pada pelaksanaan implementasi kebijakan penanganan dan pengendalian covid-19 pada sektor pariwisata di Kota Tomohon, peneliti memberi masukan dalam hal ini beberpa saran yang terdiri dari :

\section{Pembuat Kebijakan (Decision Maker)}

Perwako Kota Tomohon nomor 28 Tahun 2020 untuk segera dibuatkan undang undang yang merinci tentang penerapan protokol kesehatan dalam hal ini untuk penanganan dan pengendalian covid-19.

\section{Implementor}

Secara keseluruhan, khususnya di obyekobyek wisata, disediakan staf atau implementor yang memang khusus ditempatkan untuk membantu mengawasi pelaksanaan protokol misalnya dengan bantuan Satuan Polisi Pamong Praja.

\section{Kelompok Sasaran}

Kelompok sasaran yang dimaksud dalam penelitian yaitu para wisatawan yang berkunjung ke obyek-obyek pariwisata serta tempat - tempat pariwisata lain hendaknya untuk tetap menerapkan protokol kesehatan seperti memakai masker, mencuci tangan dan menjaga jarak antar satu dengan yang lain serta tidak menyebabkan kerumunan karena pada intinya kebijakan penanganan dan pengendalian covid-19 pada sektor pariwisata khususnya di Kota Tomohon bertujuan untuk melindungi keselamatan masyarakat itu sendiri.

\section{DAFTAR PUSTAKA}

Ardika, I Wayan. 2007. Pustaka Budaya dan Pariwisata. Denpasar. Pustaka Larasan.

Basuki, S. 2006. Metode Penelitian. Jakarta: Wedatama Widya Sastra.

Maklumat Wali Kota Tomohon nomor 67/WKT/IV-2020 tentang penegasan pelaksanaan himbauan pemerintah dalam penanganan penyebaran covid-19.
Miles, B. Mathew dan Michael Huberman. 1992. Analisis Data Kualitatif Buku Sumber Tentang Metode-metode Baru. Jakarta: UIP.

Peraturan Wali Kota (Perwako) Tomohon Nomor 28 Tahun 2020 tertanggal 1 September 2020, tentang penerapan disiplin dan penegakan hukum protokol kesehatan sebagai upaya pengendalian covid-19.

Widodo. 2011. Analisis Kebijakan Publik: Konsep dan Aplikasi Analisis Proses Kebijakan Publik. Malang: Bayu Media.

https://sindomanado.com/2020/03/24/tempatwisata-dan-hiburan-malam-di-kotatomohon-ditutup/ Diakses 08 Juli 2020, 10.35 PM. 